\title{
Aplikasi Sistem Pakar Berbasis Mobile Untuk Diagnosis Dini Meningitis
}

\author{
Mona Pradipta Hardiyanti ${ }^{*}$, R. Rizal Isnanto, Ike Pertiwi Windasari \\ Departemen Teknik Sistem Komputer, Fakultas Teknik, Universitas Diponegoro \\ Jl. Prof. Soedarto, SH, Kampus Undip Tembalang, Semarang, Indonesia 50275
}

\begin{abstract}
In Indonesia, cases of meningitis happen quite a lot because meningitis patients are not aware that he was infected with meningitis. This is because the early symptoms resemble regular headaches. Lack of community information about a disease and its symptoms and causes make the process of treatment is slow so it can make the disease worse and fatal. This research is devoted to makes of meningitis expert system that can be used by the public to solve the problem. This expert system is developed using Expert System Development Life Cycle (ESDLC). The steps to create an expert system using this method are assessment, acquisition of knowledge, design, and testing. This application tested using black box testing methods and directly testing by an expert. Based on test results showed a qualitative testing that system there is no error of its functions. Application of expert system can make the process of diagnosis according to the data obtained from the experts. For renew of disease and symptoms, it can be done by modifying the database.
\end{abstract}

Keywords - meningitis; expert system; ESDLC; MySQL; forward chaining

Abstrak - Di Indonesia kasus meningitis terjadi cukup banyak dikarenakan penderita meningitis yang tidak mengetahui bahwa dirinya terserang meningitis. Hal ini karena gejala awal penyakit menyerupai sakit kepala biasa. Kurangnya informasi masyarakat tentang suatu penyakit beserta gejala dan penyebabnya membuat proses penanganannya menjadi lambat sehingga dapat membuat penyakit semakin parah dan berakibat fatal. Penelitian ini dikhususkan untuk pembuatan sistem pakar meningitis yang bisa digunakan oleh masyarakat memecahkan masalah tersebut. Sistem pakar dibuat dengan metodologi Expert System Development Life Cycle (ESDLC). Langkah pembuatan sistem pakar menggunakan metode ini adalah penilaian, akuisisi pengetahuan, desain, dan pengujian. Pengujian aplikasi ini menggunakan metode pengujian kotak hitam dan pengujian langsung oleh pakar. Berdasarkan hasil pengujian didapatkan hasil pengujian secara kualitatif bahwa sistem tidak terdapat kesalahan dalam menjalankan fungsifungsinya. Aplikasi sistem pakar dapat melakukan proses diagnosis penyakit sesuai data yang didapatkan dari pakar. Untuk memperbarui penyakit dan gejala dilakukan dengan cara merubah basisdata.

*) Penulis korespondensi (Mona Pradipta Hardiyanti)

Email: mona.peha@gmail.com
Kata Kunci - meningitis; sistem pakar; ESDLC; MySQL; forward chaining

\section{Pendahuluan}

Meningitis termasuk ke dalam sepuluh macam penyakit paling berbahaya di dunia yang sering menyerang anak - anak. Meningitis adalah infeksi pada meninges (selaput pelindung) yang menyelimuti otak dan saraf tulang belakang. Ketika meradang, meninges membengkak karena infeksi yang terjadi [1]. Setiap tahun, lebih dari 400 juta orang yang tinggal di 26 negara terserang meningitis. Kasus meningitis paling banyak terjadi di negara-negara Afrika dengan lebih dari 900.000 kasus dalam rentang tahun 1995-2014. Dari kasus ini, 10\% mengakibatkan kematian, dengan $10-20 \%$ mengembangkan gejala sisa neurologis lain [2]. Perkembangan teknologi dan pengetahuan dunia kedokteran modern telah menemukan berbagai cara mencegah terjadinya penyakit, khususnya penemuan teknologi modern vaksinasi. Meskipun vaksin memiliki efektivitas yang tinggi, tetapi itu tidak $100 \%$ menjamin bahwa seseorang tidak akan terserang suatu penyakit [3].

Banyak teknologi yang dibuat untuk mengurangi angka kematian yang disebabkan oleh kurang cepatnya penanganan pasien yang terinfeksi meningitis karena ketidaktahuan penderita bahwa penyakit yang menginfeksi tersebut adalah meningitis. Perkembangan teknologi yang menghasilkan produk dengan mengimplementasikan ilmu kecerdasan buatan dapat melalui pengembangan sebuah aplikasi untuk dapat menghasilkan suatu keputusan. Salah satunya adalah penggunaan konsep sistem pakar. Sistem ini dirancang untuk menirukan keahlian seorang pakar dalam menjawab pertanyaan dan menyelesaikan suatu permasalahan baik di bidang kesehatan atau kedokteran, bisnis, ekonomi dan sebagainya.

Implementasi sistem pakar pada dunia kedokteran atau kesehatan dapat berupa diagnosis penyakit, konsultasi penjagaan kesehatan hingga pemberian saran penentuan solusi dari hasil diagnosis yang ada dengan cepat dan tepat. Sistem pakar ini diaplikasikan untuk diagnosis beragam penyakit dan diimplementasikan pada berbagai platform perangkat lunak [4]-[9]. Dhany [4] mengembangkan sistem pakar pendeteksi berbagai macam penyakit yang menyerang anak termasuk meningitis. Secara khusus, Widiastuti dkk. [5] membuat aplikasi pakar untuk tuberkulosis. Ramdhani dkk. [6] mengembangkan sistem pakar untuk deteksi hepatitis menggunakan metode certainty factor. Malvianto [7] mengembangkan aplikasi sistem pakar berbasis perangkat bergerak untuk diagnosis awal 
gangguan kesehatan dengan menggunakan bahasa pemograman Java yang dapat memberikan informasi hasil diagnosis awal dari gangguan kesehatan berupa kemungkinan penyebab serta saran tindakan sendiri yang bisa dilakukan untuk mengatasi kemungkinan penyebabnya. Kurniawati [8] mengembangkan aplikasi sistem pakar diagnosis penyakit menular pada anak berbasis Android dengan 10 macam penyakit yaitu Tuberkulosis, batuk rejan, cacar air, campak jerman, campak, demam kelenjar, Nefritis, Polio, Meningitis, dan Pneumonia. Naser dkk. [9] mengembangkan sistem pakar ESDMA (Expert System for Medical Diagnostic Assistance) yang dibangun menggunakan CLIPS ( $C$ Language Integrated Production System) dan dapat digunakan untuk mendeteksi beberapa macam penyakit serta memberikan anjuran yang tepat kepada mereka. Jumiyati dan Pramono [10] mengembangkan aplikasi pakar diagnosis penyakit paru pada anak dengan metode logika fuzzy di perangkat Android.

Penelitian-penelitian di atas membuat sistem pakai untuk deteksi penyakit yang ditujukan untuk segmen pengguna khusus [4],[8],[10], untuk penyakit khusus [5],[6],[10] dan beragam penyakit atau gangguan [4],[7]-[9]. Metode inferensinya pun beragam, yaitu runut maju [4],[5],[7]-[9], certainty factor [6] dan logika fuzzy [10]. Artikel ini membahas tentang pengembangan aplikasi deteksi penyakit Meningitis, bernama "Awas Meningitis!". Aplikasi "Awas Meningitis!" dijalankan di perangkat bergerak platform Android sehingga orang bisa menggunakannya untuk mendiagnosis awal apakah terinfeksi meningitis dan bisa secepatnya ditangani oleh dokter. Penelitian ini difokuskan pada satu penyakit saja yaitu meningitis, yaitu meningitis bakterialis akut dan meningitis tuberkulosis. Metode yang digunakan adalah runut maju.

\section{Metode Penelitian}

Penelitian menggunakan ESDLC (Expert System Development Life Cycle) yang terdiri dari tahap penilaian keadaan, koleksi pengetahuan, perancangan sistem, dan pengujian. Tahap pertama dalam pengembangan sistem adalah tahap penilaian keadaan. Tahapan ini merupakan proses menganalisis masalah dan kebutuhan terkait dengan permasalahan penyakit Meningitis dan kebutuhan sistem. Tahapan ini dilakukan guna mengambil data dan kemudian dilakukan analisis berdasarkan studi literatur yang digunakan. Hasil dari tahap ini adalah daftar kebutuhan fungsional dan non fungsional sistem.

Tahap kedua adalah koleksi pengetahuan. Tahapan ini merupakan proses untuk mendapatkan pengetahuan tentang penyakit Meningitis dan digunakan sebagai panduan dalam pengembangan. Pengetahuan ini digunakan untuk memberikan informasi dalam mendesain sistem pakar. Tahap ini meliputi studi dengan diadakannya pertemuan dengan pakar untuk membahas aspek dari permasalahan.

Tahap ketiga adalah tahap perancangan sistem. Berdasarkan pengetahuan yang telah didapatkan dalam
Tabel 1. Gejala penyakit meningitis

\begin{tabular}{cl}
\hline Penyakit & \multicolumn{1}{c}{ Gejala } \\
& a. Demam (G01) \\
& b. Muntah-muntah (G02) \\
Meningitis & c. Nyeri kepala (G03) \\
Bakterialis & d. Penurunan kesadaran (G04) \\
Akut & e. Fotofobia (intoleransi terhadap \\
(P01) & \multicolumn{1}{c}{ cahaya terang) (G05) } \\
& f. Kejang hemiparesis (G06) \\
& g. Kaku kuduk (G07) \\
& a. Demam (G01) \\
& b. Muntah-muntah (G02) \\
Meningitis & c. Nyeri Kepala (G03) \\
Tuberkulosis & d. Malaise (perasaan tidak nyaman, \\
(P02) & tidak sehat, atau lesu) (G08) \\
& f. Anoreksia (kurus) (G09) \\
& (G10)
\end{tabular}

proses koleksi pengetahuan, maka desain antarmuka maupun teknik penyelesaian masalah dapat diimplementasikan ke dalam sistem pakar. Pada tahap ini dilakukan perancangan desain tampilan dan antarmuka sistem, desain basis data sistem, serta cara kerja sistem. Kemudian, hasil dari perancangan yang telah dibuat diimplementasikan ke dalam aplikasi sistem pakar. Aplikasi dibuat dengan JQuery Mobile. JQuery Mobile adalah sistem antarmuka pengguna berbasis HTML5 yang dirancang untuk membuat situs web responsif dan aplikasi yang dapat diakses di semua perangkat telepon cerdas (smartphone), tablet dan desktop [11].

Tahap terakhir adalah tahap pengujian sistem. Tahap ini dimaksudkan untuk menguji apakah sistem pakar yang dibangun telah sesuai dengan tujuan pengembangan maupun kesesuaian kinerja sistem dengan metode penyelesaian masalah yang bersumber dari pengetahuan yang sudah didapatkan. Apabila dalam tahap ini terdapat bagian yang harus dievaluasi maupun dimodifikasi maka hal tersebut harus segera dilakukan agar sistem pakar dapat berfungsi sebagaimana tujuan pengembangannya. Pengujian pakar dilakukan oleh dr. Aris Catur Bintoro, Sp.S bagian Staf Medis Fungsional (SMF) Neurologi RSUP Dr. Kariadi Semarang. Proses validasi dari pengujian ini adalah dengan membandingkan apakah hasil diagnosis menggunakan sistem pakar sudah sesuai dengan gejala-gejala penyakit yang dipilih.

\section{HASIL DAN PEMBAHASAN}

Basis pengetahuan yang didapatkan dari pakar mengenai gejala-gejala penyakit meningitis ditunjukkan pada Tabel 1. Basis pengetahuan pakar ini akan menjadi aturan produksi sistem. Pembuatan basis data dilakukan dengan menggunakan database MySQL yang di dalamnya terdapat basis pengetahuan pakar. Tabel yang dibuat adalah tabel diagnosis seperti ditunjukkan pada Tabel 2 .

Jurnal Teknologi dan Sistem Komputer, 5(2), 2017, 84 
Tabel 2. Tabel Diagnosis

\begin{tabular}{|c|c|c|c|c|c|}
\hline ID & solusi dan pertanyaan & bila benar & bila salah & mulai & selesai \\
\hline 1 & $\begin{array}{l}\text { Apakah Anda mengalami } \\
\text { deman? }\end{array}$ & 2 & 13 & $\mathrm{Y}$ & $\mathrm{N}$ \\
\hline 2 & $\begin{array}{l}\text { Apakah Anda mengalami } \\
\text { muntah-muntah? }\end{array}$ & 3 & 13 & $\mathrm{~N}$ & $\mathrm{~N}$ \\
\hline 3 & $\begin{array}{l}\text { Apakah Anda mengalami } \\
\text { nyeri kepala? }\end{array}$ & 4 & 13 & $\mathrm{~N}$ & $\mathrm{~N}$ \\
\hline 4 & $\begin{array}{l}\text { Apakah Anda mengalami } \\
\text { penurunan kesadaran? }\end{array}$ & 6 & 5 & $\mathrm{~N}$ & $\mathrm{~N}$ \\
\hline 5 & $\begin{array}{l}\text { Apakah Anda mengalami } \\
\text { malaise atau perasaan } \\
\text { tidak nyaman? }\end{array}$ & 7 & 6 & $\mathrm{~N}$ & $\mathrm{~N}$ \\
\hline 6 & $\begin{array}{l}\text { Apakah Anda mengalami } \\
\text { fotofobia atau intoleransi } \\
\text { terhadap cahaya terang? }\end{array}$ & 8 & 7 & $\mathrm{~N}$ & $\mathrm{~N}$ \\
\hline 7 & $\begin{array}{l}\text { Apakah Anda mengalami } \\
\text { anoreksia atau badan } \\
\text { kurus? }\end{array}$ & 9 & 8 & $\mathrm{~N}$ & $\mathrm{~N}$ \\
\hline 8 & $\begin{array}{l}\text { Apakah Anda mengalami } \\
\text { kejang hemiparesis atau } \\
\text { sebagian? }\end{array}$ & 10 & 9 & $\mathrm{~N}$ & $\mathrm{~N}$ \\
\hline 9 & $\begin{array}{l}\text { Apakah Anda mengalami } \\
\text { nyeri di bagian abdomen } \\
\text { atau perut? }\end{array}$ & 11 & 10 & $\mathrm{~N}$ & $\mathrm{~N}$ \\
\hline 10 & $\begin{array}{l}\text { Apakah Anda mengalami } \\
\text { kaku kuduk? }\end{array}$ & 12 & 11 & $\mathrm{~N}$ & $\mathrm{~N}$ \\
\hline 11 & $\begin{array}{l}\text { Dari gejala yang Anda } \\
\text { pilih hasil diagnosis } \\
\text { adalah Meningitis } \\
\text { Tuberkulosis }\end{array}$ & 0 & 0 & $\mathrm{~N}$ & $\mathrm{Y}$ \\
\hline 12 & $\begin{array}{l}\text { Dari gejala yang Anda } \\
\text { pilih hasil diagnosis } \\
\text { adalah Meningitis } \\
\text { Bakterialis Akut }\end{array}$ & 0 & 0 & $\mathrm{~N}$ & $\mathrm{Y}$ \\
\hline 13 & $\begin{array}{l}\text { Anda mungkin tidak } \\
\text { terkena penyakit } \\
\text { Meningitis }\end{array}$ & 0 & 0 & $\mathrm{~N}$ & $\mathrm{Y}$ \\
\hline
\end{tabular}

Pada struktur tabel diagnosis, terdapat beberapa atribut dan yang paling penting adalah atribut id sebagai primary key. Atribut lainnya adalah solusi_dan_pertanyaan, bila_benar, bila_salah, mulai, dan selesai. Pada kolom atau atribut 'solusi_dan_pertanyaan' dituliskan pertanyaanpernyataan gejala yang akan ditampilkan kepada pengguna. Pada kolom 'bila_benar' berisi id dari pertanyaan selanjutnya yang akan ditanyakan kepada pengguna setelah pengguna menjawab suatu pertanyaan, begitu pula dengan kolom 'bila_salah', pada tabel terlihat pada halaman diagnosis pertanyaan dengan id 1 akan berlanjut ke pertanyaan dengan id 3 apabila pengguna menjawab Ya, sedangkan apabila pengguna menjawab Tidak maka akan berlanjut ke pertanyaan dengan id 2. Kolom 'mulai' dan 'selesai' menentukan apakah pertanyaan gejala akan ditampilkan. Pada tabel terlihat pada id 1 'mulai' berisi Y yang berarti Yes dan 'selesai' berisi N yang berarti No sehingga pertanyaan tersebut akan ditampilkan dan berlanjut ke pertanyaan selanjutnya karena proses belum selesai. Sedangkan pada id 11 dan 12 mulai berisi $\mathrm{N}(\mathrm{No})$ dan selesai berisi Y (Yes) yang berarti bahwa tidak ada pertanyaan gejala yang akan ditampilkan lagi karena proses sudah selesai dan menampilkan diagnosis penyakit yaitu penyakit meningitis bakterialis akut atau meningitis tuberkulosis. Pohon keputusan dari sistem pakar Awas Meningitis ditunjukkan pada Gambar 1.

Pembuatan tampilan atau antarmuka sistem adalah berdasarkan desain yang telah dirancang sebelumnya. Desain yang dirancang meliputi halaman awal atau halaman utama dan halaman konsultasi dari

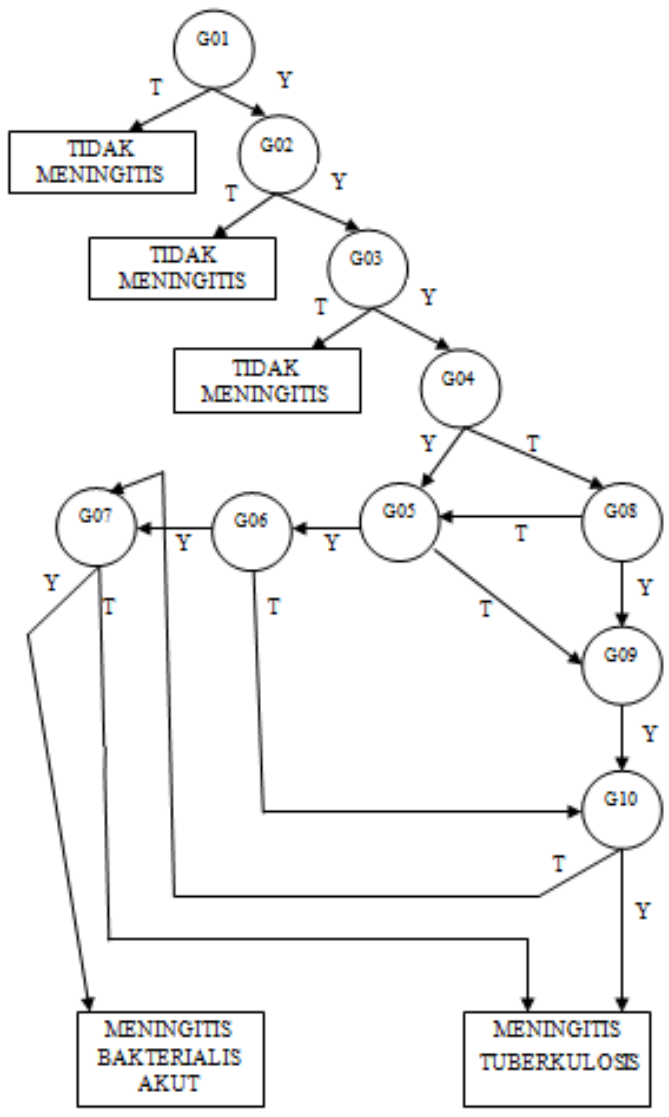

Gambar 1. Pohon keputusan sistem pakar

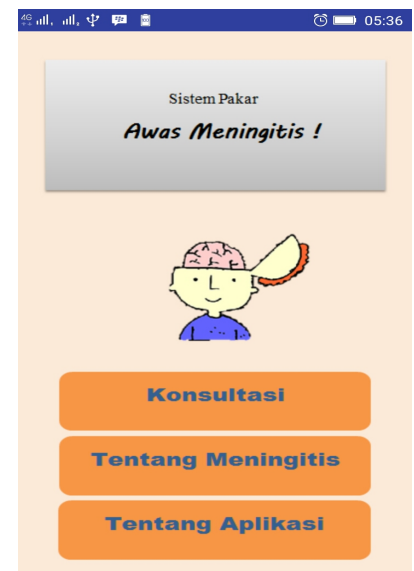

Gambar 2. Halaman awal aplikasi

aplikasi sistem pakar Awas Meningitis!. Halaman awal aplikasi ditunjukkan pada Gambar 2.

Pada halaman ini, terdapat 3 menu utama yaitu menu Konsultasi, menu Tentang Meningitis, dan menu Tentang Aplikasi. Ketika pengguna meng-klik menu Tentang Meningitis maka akan masuk ke halaman tentang meningitis yang terdapat dua pilihan informasi. Informasi pertama mengenai deskripsi serta jenis-jenis meningitis. Informasi kedua adalah cara pencegahan dan penanganan meningitis. Hal-hal apa saja yang dapat dilakukan untuk mencegah agar tidak terjangkiti meningitis dan hal-hal apa saja yang bisa dilakukan apabila sudah terjangkiti meningitis seperti ditunjukkan pada Gambar 3. 


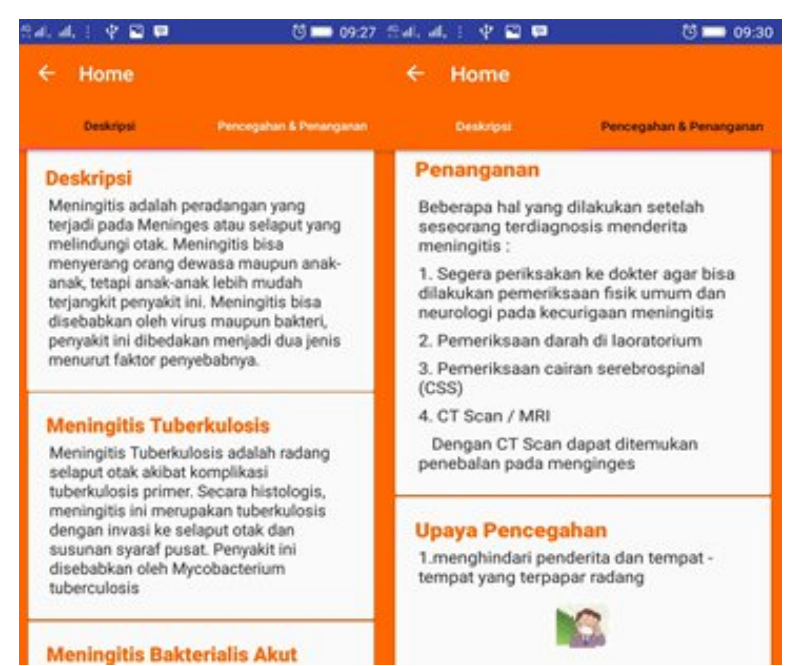

Gambar 3. Halaman Tentang Meningitis

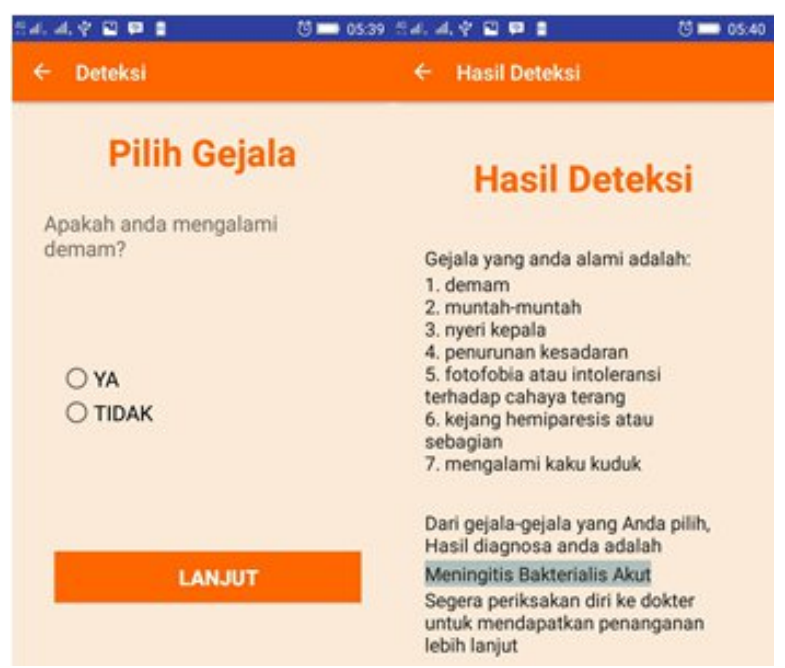

Gambar 4. Halaman Konsultasi

Ketika pengguna meng-klik menu Konsultasi pada halaman utama, maka akan diarahkan ke Halaman konsultasi yang merupakan halaman inti aplikasi. Pada halaman ini akan ditampilkan gejala secara bergantian dan pengguna bisa mengisi Ya/Tidak. Pengguna diwajibkan memilih tiga (3) buah gejala wajib Meningitis untuk diproses oleh sistem. Gejala yang wajib dipilih adalah demam, nyeri kepala, dan muntahmuntah. Apabila pengguna tidak memilih tiga buah gejala wajib itu, maka aplikasi akan menampilkan pesan bahwa pengguna tidak terindikasi penyakit meningitis. Setelah pengguna memilih beberapa gejala yang ingin di-diagnosis, maka selanjutnya pengguna meng-klik tombol LANJUT ditunjukkan pada Gambar 4.

Tahapan pengujian sistem menggunakan pengujian kotak hitam dan diuji langsung oleh pakar yaitu dokter spesialis saraf. Hasil pengujian fungsi umum (fungsionalitas) dengan metode kotak hitam pada aplikasi sistem pakar Awas Meningitis! ditunjukkan pada Tabel 3.
Tabel 3. Pengujian fungsional sistem pakar

\begin{tabular}{|c|c|c|c|}
\hline Pengujian & Tindakan & $\begin{array}{l}\text { Hasil yang } \\
\text { Diinginkan }\end{array}$ & Hasil \\
\hline $\begin{array}{l}\text { Menu } \\
\text { Home }\end{array}$ & $\begin{array}{l}\text { Mengakses } \\
\text { halaman } \\
\text { utama } \\
\text { aplikasi }\end{array}$ & $\begin{array}{l}\text { Menampilkan } \\
\text { halaman utama } \\
\text { yang berisi } \\
\text { nama aplikasi, } \\
\text { gambar aplikasi, } \\
\text { dan beberapa } \\
\text { pilihan menu } \\
\text { aplikasi. }\end{array}$ & Berhasil \\
\hline $\begin{array}{l}\text { Menu } \\
\text { Tentang } \\
\text { Aplikasi }\end{array}$ & $\begin{array}{l}\text { Mengakses } \\
\text { halaman } \\
\text { Tentang } \\
\text { Aplikasi } \\
\text { dengan } \\
\text { meng-klik } \\
\text { Tombol } \\
\text { Tentang } \\
\text { Aplikasi }\end{array}$ & $\begin{array}{l}\text { Menampilkan } \\
\text { menu Tentang } \\
\text { Aplikasi yang } \\
\text { berisi deskripsi } \\
\text { Aplikasi dan } \\
\text { tentang } \\
\text { pengembang } \\
\text { aplikasi }\end{array}$ & Berhasil \\
\hline $\begin{array}{l}\text { Menu } \\
\text { Tentang } \\
\text { Meningitis }\end{array}$ & $\begin{array}{l}\text { Mengakses } \\
\text { halaman } \\
\text { Meningitis } \\
\text { dengan } \\
\text { meng-klik } \\
\text { tombol } \\
\text { Tentang } \\
\text { Meningitis } \\
\text { pada } \\
\text { halaman } \\
\text { Home }\end{array}$ & $\begin{array}{l}\text { Menampilkan } \\
\text { halaman } \\
\text { deskripsi serta } \\
\text { penanganan dan } \\
\text { pencegahan } \\
\text { meningitis }\end{array}$ & Berhasil \\
\hline $\begin{array}{l}\text { Menu } \\
\text { Konsultasi }\end{array}$ & $\begin{array}{l}\text { Mengakses } \\
\text { halaman } \\
\text { Konsultasi } \\
\text { dengan }\end{array}$ & $\begin{array}{l}\text { Menampilkan } \\
\text { gejala-gejala } \\
\text { yang dapat } \\
\text { dipilih oleh } \\
\text { pengguna }\end{array}$ & Berhasil \\
\hline $\begin{array}{l}\text { Tombol } \\
\text { Ya pada } \\
\text { halaman } \\
\text { konsultasi }\end{array}$ & $\begin{array}{l}\text { Mengklik } \\
\text { tombol Ya } \\
\text { pada } \\
\text { jawaban } \\
\text { pertanyaan } \\
\text { gejala yang } \\
\text { ditampilkan }\end{array}$ & $\begin{array}{l}\text { Akan } \\
\text { menyimpan } \\
\text { bahwa } \\
\text { pengguna } \\
\text { menjawab Ya }\end{array}$ & Berhasil \\
\hline $\begin{array}{l}\text { Tombol } \\
\text { Tidak } \\
\text { pada } \\
\text { halaman } \\
\text { konsultasi }\end{array}$ & $\begin{array}{l}\text { Mengklik } \\
\text { tombol } \\
\text { Tidak pada } \\
\text { jawaban } \\
\text { pertanyaan } \\
\text { gejala }\end{array}$ & $\begin{array}{l}\text { Akan } \\
\text { menyimpan } \\
\text { bahwa } \\
\text { pengguna } \\
\text { menjawab } \\
\text { Tidak }\end{array}$ & Berhasil \\
\hline
\end{tabular}

Pengujian pakar pada aplikasi sistem pakar “Awas Meningitis!" berfungsi untuk validasi hasil diagnosis. Pengujian pakar dilakukan secara objektif dimana aplikasi diuji secara langsung apakah hasil diagnosis sesuai dengan gejala-gejala yang sudah diberikan oleh pakar sebelumnya. Pengujian oleh pakar ditunjukkan pada Gambar 5. 


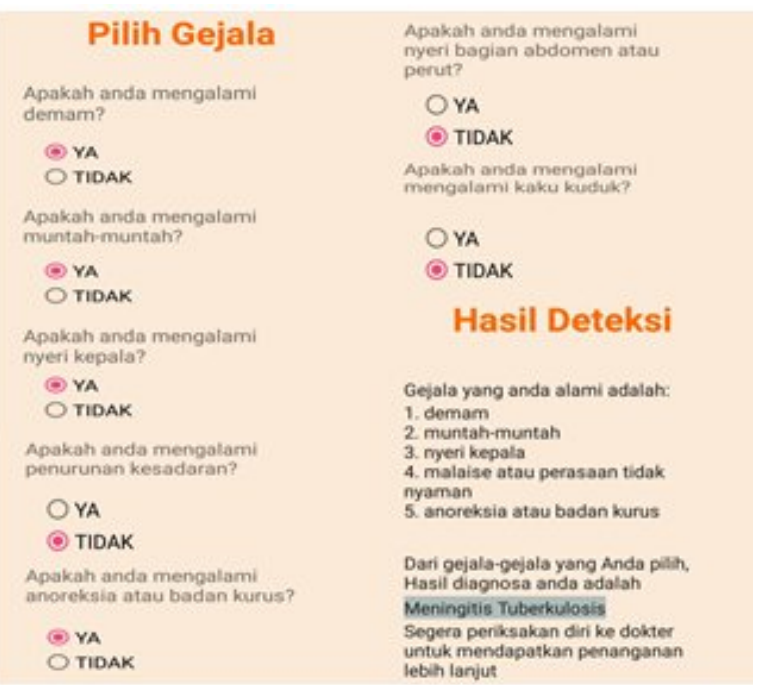

Gambar 5. Pengujian pakar

Tabel 4. Perbandingan gejala penyakit dengan hasil diagnosis

\begin{tabular}{lll}
$\begin{array}{c}\text { Penyakit } \\
\text { Hasil } \\
\text { Diagnosis }\end{array}$ & Gejala Penyakit & $\begin{array}{c}\text { Gejala yang } \\
\text { dipilih pada } \\
\text { sistem pakar }\end{array}$ \\
\hline Meningitis & a. Nyeri kepala & a. Demam \\
Tuberkulosis & b. Muntah- & b. Muntah-mun- \\
& muntah & tah \\
& c. Demam & c. Nyeri kepala \\
& d. Anoreksia & d. Malaise \\
& (kurus) & e. Anoreksia \\
& e. Malaise & \\
& (perasaan & \\
& tidak & \\
& $\begin{array}{l}\text { nyaman, } \\
\text { tidak sehat, }\end{array}$ & \\
& atau lesu) & \\
& f. Nyeri & \\
& abdomen \\
& (daerah perut) \\
& & \\
&
\end{tabular}

Dari percobaan sistem pakar tersebut oleh pakar, dibuatlah perbandingan antara gejala yang dipilih oleh pakar pada aplikasi dengan gejala-gejala penyakit sesungguhnya. Hasil perbandingannya ditunjukkan dalam Tabel 4.

Hasil diagnosis dengan gejala-gejala yang dipilih sudah sesuai. Pakar yang melakukan pengujian aplikasi memilih 5 dari 6 gejala Meningitis Tuberkulosis. Form pengujian dari pakar ditunjukkan pada Gambar 6.

Secara fungsional, aplikasi ini sudah berfungsi dengan baik untuk mendiagnosis penyakit Meningitis berdasarkan gejala-gejala yang terjadi, baik meningitis bakterialis akut maupun tuberkulosis. Aplikasi ini dapat digunakan untuk deteksi dini penyakit meningitis seperti halnya [4]-[10]. Metode runut maju di sistem pakar ini telah dapat memberikan penalaran deteksi penyakit berdasarkan gejala-gejala yang diberikan oleh pengguna.

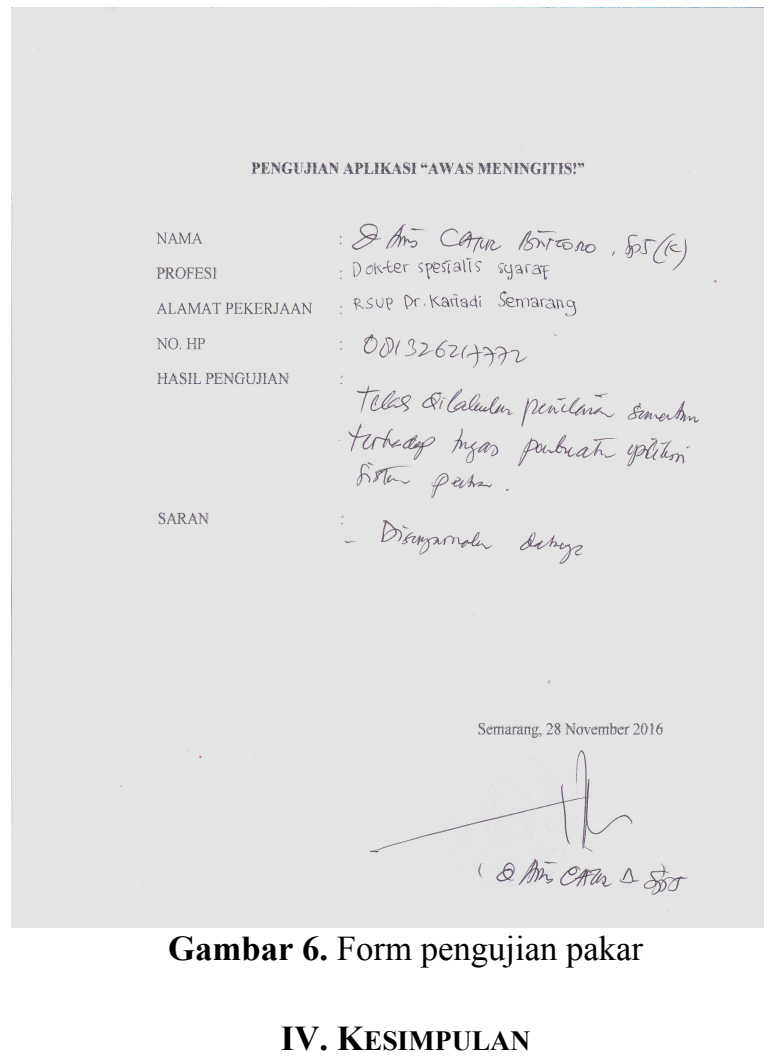

Aplikasi sistem pakar "Awas Meningitis!" dapat melakukan proses diagnosis penyakit sesuai data rekomendasi yang didapatkan dari pakar. Aplikasi ini dapat terbentuk sesuai dengan kebutuhan utama yang diharapkan dari pengguna, hasil pengujian sistem dengan kotak hitam menunjukkan bahwa sistem tidak memiliki kesalahan dalam menjalankan fungsi-fungsi, untuk pembaharuan penyakit dan gejala dilakukan dengan cara mengubah basis data.

Berdasarkan pengujian terhadap aplikasi "Awas Meningitis!" sistem pakar pendeteksi penyakit Meningitis berbasis mobile, sistem pakar dapat dikembangkan lebih lanjut dengan mengintegrasikannya terhadap sistem pakar lain misal penyakit yang berhubungan dengan saraf ataupun yang berhubungan dengan kepala, pembuatan sistem pakar ini ke dalam bentuk website sehingga data pada sistem dapat dikelola lebih baik, sistem pakar ini dapat dikembangkan lebih lanjut dengan menambah fungsi-fungsi seperti login, menambah, mengubah dan menghapus data penyakit dan basis data bersifat online sehingga data penyakit selalu terbaru mengikuti perkembangan ilmu penyakit meningitis, dan memperbaiki dan memperindah tampilan antarmuka untuk menyajikan kenyamanan penggunaan oleh pengguna.

\section{UCAPAN TERIMA KASIH}

Ucapan terima kasih disampaikan kepada dr. Aris Catur Bintoro, Sp.S dari bagian Staf Medis Fngsional (SMF) Neurologi RSUP Dr. Kariadi Semarang yang telah memberikan bimbingan serta pengetahuan mengenai penyakit meningitis. 


\section{Daftar Pustaka}

[1] Kelompok Studi Neuro Infeksi, Infeksi Pada Sistem Saraf, Surabaya: Pusat Penerbitan dan Percetakan UNAIR, 2011.

[2] \# WHO, "Meningococcal Meningitis, "WHO, July 3, 2015, [Online]. Available: http://www.who.int/csr/disease/meningococcal/en/ [Diakses 15 Maret 2016].

[3] Rahmatiah, "Pengaruh Vaksinasi Terhadap Kekebalan Tubuh Bayi”. Ebuletin LPMP Sulsel, April 2015. [Online]. Available: http://www.lpmpsulsel.net/v2/attachments/343_Pen garuh\%20Vaksinasi\%20Terhadap\%20Bayi.pdf. [Diakses 17 Maret 2016].

[4] S. Dhany, "Perancangan Sistem Pakar Untuk Diagnosa Penyakit Anak, " Skripsi S1, Universitas Sumatera Utara, Medan, 2009.

[5] W. Widiastuti, D. Destiani, dan D. J. Dhamiri, "Aplikasi Sistem Pakar Deteksi Dini Pada Penyakit Tuberkulosis," Jurnal Sekolah Tinggi Teknologi Garut, 2012.

[6] A. Ramdhani, R. R. Isnanto, I. P. Windasari, "Pengembangan Sistem Pakar Untuk Diagnosis
Hepatitis Berbasis Web Menggunakan Metode Certainty Factor". Jurnal Teknologi dan Sistem Komputer, vol.3, no.1, Januari 2015. doi: http://dx.doi.org/10.14710/jtsiskom.3.1.2015.58-64.

[7] D. R. Malvianto, “Aplikasi Sistem Pakar Berbasis Mobile Device Untuk Diagnosa Awal Gangguan Kesehatan, " Skripsi S1, Universitas Komputer Indonesia, Bandung, 2010.

[8] D. Kurniawati, "Aplikasi Sistem Pakar Diagnosa Penyakit Menular Pada Anak Berbasis Android," Universitas Gunadarma, 2013. [Online]. Available: http://library.gunadarma.ac.id/repository/view/3766 429

[9] S. A. Naser, R. A. Dahdooh, A. Mushtaha, and M. E. Naffar, "Knowledge Management in ESMDA : Expert System for Medical Diagnostic Assistance," ICGST-AIML Journal, vol.10, p.34, October 2010.

[10] M. Jumiyati, B. Pramono, "Aplikasi Sistem Pakar Diagnosis Penyakit TB Paru pada Anak dengan Metode Logika Fuzzy Berbasis Android,", semanTIK, vol. 1, no. 1, 2015.

[11] jQuery Foundation, "A Touch-Optimized Web Framework," [Online]. Available: http://jquerymobile.com. [Diakses 30 Maret 2016]. 